\title{
Vygotsky's Hamlet: the dialectic method and personality Psychology
}

\author{
Larisa F. Bayanova \\ Kazan Federal University, Kazan, Russia
}

\begin{abstract}
This article presents an analysis of Vygotsky's work on the psychology of art and his use of the image of Hamlet in the psychological analysis of personality. It also describes the capabilities of the dialectic method for assessing psychological problems. Reference to three dialectical oppositions-of the story and the plot, of the main character's spinelessness and his insanity, and of subject and personality-allows the development of a theoretical analysis of the psychology of personality in its relationship to culture. Culture is defined as the system of normative situations.
\end{abstract}

Keywords: image of Hamlet, dialectic method, culture, normative situation, personality, subject

The topicality of L. S. Vygotsky's research in the sphere of psychology of art is connected to the methodological potential of his works, in which a special role belongs to his work on Hamlet. The historical context for the creation of art psychology by Vygotsky during twenty years of the last century has been associated with active philosophical discussion on the topic of the interaction between people and the world. The idea of the birth of personality and self-identity through resistance and creativity was the main line of the theoretical thought of those years; Frank (1971) called this line "the problem of the subject." The need for personal selfrealization through creativity was at the heart of Russian philosophy in the first third of the twentieth century, and, in my opinion, the spokesperson for that idea was the philosopher N. A. Berdyaev, who formulated the concept of the existential dialectic:

Self-realization of the individual suggests resistance, requires struggle against the enslaving power of the world, against conformity with the world. Rejection of identity, disagreement with the dissolution in the surrounding world, may reduce the pain, and a person can easily go that way. Consent to slavery reduces pain, disagreement increases pain. (Berdyaev, 2000, p. 23)

For Berdyaev, a person is born into resistance for the sake of creativity: "Personality is essentially rebellious and disobedient; it is resistance, a continuous creative act" (Berdyaev, 2000, p. 37). The dialectics of the personality's birth through 
art are shown in the works of the Russian philosopher and psychologist M. Rubinstein, who is, unfortunately, almost forgotten. One of my articles is devoted to his oeuvre (Bayanova, 2009).

In the beginning the problem of the interaction between people and the world arose in Russian philosophy from the opposition of the subject and the object. The analysis of this opposition began in epistemology. "The human is in the world, or thrown into the world," wrote Berdyaev. "He stands before the world as before a mystery, requiring permission. The existence of a human depends on the world, and he dies in the world and because of the world" (Berdyaev,2000, p. 241) The object confronts the subject, but objectivity is in the subject, in the dominant purpose of the subject, in the existence of the object in the name of the subject. Berdyaev describes two views of the world: the cosmocentric view and the anthropocentric view. According to the cosmocentric view, people, as part of the world, located in space, experience the world, and at the limit of knowledge they turn to an object. According to the anthropocentric view, people are located not in space but in time, and they create while overcoming the limits of space.

The problem of the interaction of people and the world, initiated by the historical context, acquired a dramatic character as a problem of personal survival within culture. This problem has been presented by the art theorist, literary critic, and philosopher M. M. Bakhtin. From the general issues of human existence in the culture, Bakhtin comes to the problem of human existence in the historical and cultural situation. For Bakhtin an individual being is a "life event." He understands "the world as an event (not as existence in its readiness)" (Bakhtin, 1979, p. 364).

Rubinstein in On the Meaning of Life (1927) expresses the following thought:

Each animal is what it is; only a person is initially nothing. What he may be, he has to make himself ... and to make by his freedom. I can only be what I make from myself. At this height ... new perspectives have been opened by themselves, and as a logical consequence the man-person stands before us as the main creative force, the creator of the essence of the world (Rubinstein, p. 72).

Finding the essence of people in their involvement in the creation of culture, Rubenstein shows this fact as a turning point of cosmic significance. It opens up a new kind of freedom that is different from the natural one. According to Rubinstein people set foot on the path of self-creativity, where the essence of people is involved in the sphere of values. In the freedom of individual self-determination "a new order appears, and that is the order of obligation. The things that exist are clearly and distinctly opposed to the things that don't exist, but should exist. That is the demand and the realization of choice" (Rubinstein, 1927, p. 125).

The problem of the interaction between people and the world, identity and culture, finds vivid expression for psychology in the character of Hamlet. There are many interpretations of The Tragedy of Hamlet, Prince of Denmark, but there is only one work in psychology, which was written by Vygotsky (1987). For Vygotsky, this work is much different from his other studies. His interest in it determined the course of much of his other work because in it he found the key to individual psychology. Yaroshevsky writes that "Shakespeare's tragedy was Vygotsky's reference book until the end of his days” (Yaroshevsky, 1996, p. 114).

Vygotsky's reflections on Hamlet have not attracted enough attention from researchers in psychology today. The only exception is an article by Shchedrovitsky 
(1991), in which the author tries to explain the appeal of Hamlet's image to Vygotsky.

Vygotsky, by using Hamlet as a symbol, receives the opportunity to master himself, to answer the question of who he is in this world, which is being destroyed and built simultaneously. Vygotsky's Hamlet is interesting not only as a resolver of the social situation but also as a model for a discussion of personal issues regarding the self-determination of the end of life. By showing Hamlet's fate ... in his description and analysis, Vygotsky is actually imaging his own possible actions, building himself as a person (Shchedrovitsky, 1994, p. 85).

In my opinion, this view departs from Vygotsky's text, in which his study of Shakespeare's tragedy is focused on the art form as a means of scientific reflection on the psychological content of the individual.

Vygotsky, in his interpretation of Hamlet, adopts Gornfeld's (1912) view that every new reader of a tragedy is also a new author. Throughout his work on the Shakespearean tragedy Vygotsky focuses on the work itself; he notes that "we must take a tragedy as it is" (1987, p. 167). He openly indicts the layering of literary criticism, which prevents full psychological analysis, and he points to the need to "save Hamlet from the 11,000 volumes of comments that have crushed him with their weight" (1987, p. 167). Vygotsky writes directly that the tragedy should be the subject of psychological study that is extra-literary in its character: "Whoever wants to explore Hamlet as a psychological problem should get away from criticism altogether" (1987, p. 167).

Vygotsky, the originator of culturally historical psychology, used the image of the classical character Hamlet as a symbol in analyzing the psychology of personality. Constructing his analysis with the help of the dialectic method, Vygotsky presents several dialectic oppositions (1987). In my opinion, two of them are the most important: the opposition between the story and the plot and the contradiction between the main character's spinelessness and his insanity. The originator of the structural-dialectical approach, Veraksa, in his 1990 article "Dialectical Thinking and Creation," points out that Vygotsky typically uses the dialectic method in his scientific work (Veraksa, 1990).

Let's appeal to the first contradiction, to the opposition between the story and the plot. This opposition is discovered in the discrepancy between the unrolling plot and the story of the tragedy. The plot destroys the story in which the idea of Hamlet's revenge for his father lies. This contradiction is the basis for a special artistic form. According to Vygotsky, the artistic form in this case is "any artistic organization of the material that is introduced in order to have an esthetic effect" (Vygotsky, 1987, p. 51). Vygotsky analyzes the artistic form as the esthetic technique in which, as I suggest, a reader can discover the moment of the birth of the personality. In this sense, it is not the story of the tragedy that makes the work interesting but the artistic form introduced by Shakespeare, which reveals to the reader the sacrament of psychological birth. In Vygotsky's text this birth is emphasized in a specific way. He writes, "And Hamlet in a horrible melancholy flings his soul before the new birth" (p. 286). In general, Vygotsky's Hamlet is a person in a cultural situation-that is, a situation with a given rule that has the status of a social norm. The psychological story of the tragedy is constructed in relation to the norm. 
The second dialectic opposition is the contradiction between Hamlet's spinelessness and his insanity. Vygotsky points out that "the correct question is not why does Hamlet linger, but what does Shakespeare make Hamlet linger for?” (1987, 171). The solution of the main dialectical problem in the play lies, in my opinion, in the simultaneity of Hamlet's birth and death in two different worlds that have different regulations for normalizing a prince's behavior. The symbols of the two worlds are the Ghost and Horatio. Being in a family space Hamlet must perform certain tasks, the main goal of which is to avenge his father's death. Hamlet as the subject connected to the culture of family relationships goes beyond this goal and poses for himself the problem of "to be"; in a psychological sense, this is the problem of how to present himself as a person. His slow response brings to ruin the system of family relationships. His insanity is the achievement of a state of liberty that allows a new birth. He wants another world and another self. Hamlet builds a new norm in order "to make the image, another world, new in comparison with its global reality - a new heaven and new Earth" (Berdyaev, 1991, p. 215).

The revenge of a father as a normalizing rule of social behavior is caused by the necessity for the self-preservation of the family. The nature of the original conventional norms is such that they constitute a general agreement for common survival. Hamlet, who exists in the regulatory system, is faced with the fact that his activity is limited by regulations that govern his behavior. "The regulatory situation for which a social norm is intended is not only a means of behavior regulation but also a point where individual and social interests conflict. It limits individual behavior because of society's interests "(Veraksa, 2000, p. 90). However, in Shakespeare's tragedy we see not a social limit but Hamlet's activity aimed at the king. Here the regulatory space prescribes revenge and deprives the hero of his personality, which can be represented in the creation of new behavior that excludes revenge. In this case that is a new social norm. From a methodological and psychological point of view, personality is "a man who creates a new social (cultural) norm" (Veraksa, 2000, 96). Hamlet enters the already-prepared normative cultural organization of relationships in which he is destined to rule. Paradoxically, the possession of the highest social position, a position of absolute power, requires perfect adherence to the accepted cultural norms and control over observance of the norms. The king is the most impersonal social figure and the most accurate projection of the culture.

In the new context that Hamlet constructs, there is no Claudius, no Polonius, no Gertrude, and even no Ophelia. Hamlet died in the old world. In the new world, "the best of men"-Horatio, Laertes, and Fortinbras-enter. Friends become the symbol of the new order of human relations built by Hamlet. Horatio is selected as his executor; Hamlet trusts Horatio with his memory: "Horatio, I perish; / You're alive, to tell the truth about me / Unsatisfied” (Shakespeare, 2007, 393).

The question is why in Hamlet's new world characters enter who ignore the task of revenge. Obviously, it is because they refuse the tribal regulatory organization of the world, culture, nature. They bring a new cultural organization to human relations; they are crying out for a new Hamlet in order to have a chance for a new normative world order in which friendship may have an intrinsic value. Then there is the question of the value of love, which can also be viewed as outside the usual standards because it recognizes the value of the Other as an object of love. Why is 
Ophelia rejected by Hamlet? This too has an explanation. When Polonius orders her to deny Hamlet, Ophelia humbly replies: "I will be obedient to you, my lord." Ophelia expresses an absolute devotion to her father and easily rejects the prince's feelings, for which she is abandoned by Hamlet as a vestige of the old world. Hamlet has a goal: to be a person who requires reflection, resistance to the world, and a new social norm, which is most important. Lack of will in this case is defined only in terms of the culture to which it comes into opposition.

The interpretation of Hamlet as a hero who dwells at the crossroads of worlds is one of the most common. There is a temptation to put the dialectical contradiction as a contradiction between worlds. Thus, we find the following in Florensky's thought:

Hamlet has two principles; he is a person of two periods. He finds himself in crisis, a crisis of the spirit. There are two minds and two truths. Hamlet has no rights, and he can't recognize one of the truths as not true either; they are not compatible for a single mind. The Danish Prince is necessarily torn, and the only way out of this situation is death. But, believing that every truth is true, Hamlet has no right to run from their dispute; therefore, he can't put an end to the tragic conflict by himself. Hamlet must not kill himself, and that is the tragedy of the play (1994, p. 22).

Lack of will in this case can be viewed as the fact of Hamlet's leaving the regulatory space of tribal relations. "He erases from the pages of memories all the thoughts, feelings, all the dreams, all his life" (Vygotsky, 1987, p. 72). But the question is: After Hamlet's departure from the family's regulatory space, which was manifested in his rejection of revenge, how could the story of the tragedy develop? Hamlet should kill himself or get out of the kingdom, and neither action is consistent with any logic of the plot or of the hero's character. Turning to the second aesthetic technique of Shakespeare-the heroes' madness-let's try to explain the relevance of that condition. What is madness for Hamlet himself, who only knows "that he is not a coward" (Vygotsky, 1987, p. 173)? And what is Hamlet's madness to the others, the most astute of whom realize that this madness is a sham condition for which Hamlet has a special plan. "Though this is madness," Polonius says, "it has consistency" (Shakespeare, 2007, 133). For Mamardashvili (1996) this conscious act of going beyond culture is "the great indifference," "suspension," "clearance" (Mamardashvili, 1996, p. 32)

The phenomenon of insanity is discussed in one of Lotman's works. According to him, the crazy person is prepared for the highest honor-to be the lifeblood of culture responsible for the creation of new standards. Lotman distinguishes three types of behavior in culture, two of which are the behavior of a fool and that of a madman. The fool, like the madman, is against the norms of culture.

[But he is] deprived of a flexible response to the surrounding situation. His behavior is completely predictable. The only available form of his activity is a violation of the correct relations between the situation and the action. His actions are stereotyped, but he uses them out of place: cries at weddings, dances at a funeral. He can imagine nothing new (Lotman, 2000, p. 41)

Is Hamlet a fool? Are his actions predictable? It's worth remembering the «mousetrap» story in order to establish to ourselves that Hamlet, in the terminology of Lotman, is not a fool. Moreover, he deliberately chooses the position 
of acting in a crazy way. According to Lotman, "The one who chooses it receives additional freedom in violation of the ban; he can do things that are prohibited for the 'normal' person" (Lotman, 2000, p. 41). Thus, it appears that a fool and a madman are not synonymous but are antonymous, or, as Lotman says, they are «opposite poles.» The third behavior in Lotman's classification is «smart,» «normal» behavior, which «is described as a norm and corresponds to laws and customs» (p. 41). In our analysis the «normal Hamlet» should be a prince-avenger. However, the play depicts a spineless young man who pretends to be mad. Madness gives freedom, the opportunity for "certainty on the inside, consisting of freedom» (Berdyaev, 2000, p. 22).

Hamlet's unpredictability is dangerous to others because it brings novelty to the regulatory organization of the palace. For novelty hides the ambitious desire of Hamlet to create a new norm, his claim to be a person. Hamlet's phrase «to be or not to be," read in the light of Vygotsky's ideas, acquires a clear psychological form. Being a person (Hamlet's «to be») is defined in terms of the creation of the new, through staying outside the norms, and is accompanied by a condition of insanity, in which a person knowingly places himself or herself outside of culture, outside the rules.

Vygotsky's Hamlet is not a symbol of an era, of «coming out of a rut,» but rather a symbol of building a scientific definition of a personality, which has in psychology the status of a category. The project of building such a definition explains the interest of Vygotsky in Shakespearean tragedy in the context of the methodological problems of defining identity. Vygotsky's work on this play continued from his early years; he was able to show through the art form the definability of identity through resistance and creativity. In Vygotsky's text personality as a psychological category is not presented as the result of involvement in the creation of new rules, but we cannot disagree with the view expressed by Dyachenko (1996, p. 109) that "even those issues that Vygotsky did not directly resolve are lit in his works by the special glow of genuine creativity and hard human thought."

In addition to the two oppositions already discussed there is a third one that wasn't mentioned by Vygotsky. It is presented in dialectics of the work and is the contrast of subject and personality. The subject of culture is called to save it, but personality should change it (Bayanova, 2012). In this sense the insane and spineless behavior of Hamlet is a demonstration of his personality, which overcomes the boundaries of subjectivity in relation to the normative space of culture. That's why Hamlet-subject and Hamlet-personality meet in Shakespeare's famous phrase "to be or not to be." If the most difficult problem of psychology, the definition of personality, is to be solved through its cultural determinacy, a clear definition of culture itself as the system of normative situations hierarchically presented to a person should be disclosed. Then "personality is a person who creates a new social (cultural) norm" (Veraksa, 2000, p. 96). Hamlet's "to be or not to be" generates the alternative of the subjective and the personal position of a person in relation to the world. Either a person retains cultural constructs and thus restricts his or her freedom, or the person becomes the creator of a new rule and thus is the source of the dynamics for cultural life. The paradox of the cultural dialectic itself arises. The source is not the subject who preserves culture as a regulatory system but the person who creates 
a new standard within it. It then becomes obvious that the fundamental difference between the individual and the subject of culture is in the position they occupy in relation to cultural norms. Thus, the subject of culture is "a person who interacts with the culture as a system of regulatory situations, consciously reflecting them and complying with cultural norms in his behavior, communication, and activity" (Bayanova, 2012, p. 296), and the individual personality is a person who introduces new norms in the culture, a destroyer and a creator at the same time.

Analysis of the symbolic role of Hamlet in the psychology of the individual, which is associated with the work of Vygotsky, leads to a number of theoretical conclusions:

Vygotsky considers an art form as a way of understanding reality. Shakespeare's play, the art form that was the object of Vygotsky's study, contains two aesthetic techniques - the lack of will of the main character and his madness - that lead to a knowledge of the psychology of the individual.

Vygotsky's ideas in The Tragedy of Hamlet, Prince of Denmark correlated with humanitarian thought in the first third of the twentieth century, the source of which was the problem of individual self-realization in interaction with the world. The evaluation of culture in social, philosophical, psychological, and semiotic texts of twentieth-century authors is related to their interpretation of culture as a normative system. Personality in culture has different strategies related to cultural norms, which determine its personal existence or nonexistence (Hamlet's "to be or not to be").

In contemporary Russian psychology the explanatory schemes of cultural interaction and identity that are closest to the cultural-historical concept can be found in the structural-dialectical approach, in which a person such as Shakespeare's Hamlet is understood as the creator of a new social norm. For the history of psychology and its methodology, Vygotsky's Hamlet became a symbolic means for the analysis of personality as a psychological category described through the dialectic method.

\section{References}

Bakhtin, M. M. (1979). Estetika slovesnogo tvorchestva [The aesthetics of verbal creation]. Moscow: Iskusstvo.

Bayanova, L. F. (2009). Dialekticheskaya psyhologia M. M. Rubinsteina [The dialectical psychology of M. M. Rubinstein]. Psyhologicheskii zhurnal [National Psychological Journal], 30(6), 294-299.

Bayanova, L. F. (2012). K postanovke problemy subiekta kultury v psyhologii. [Toward the formulation of the problem of the subject of culture in psychology]. Philologia i Kultura [Philology and Culture], 3, 120-127. doi: 10.11621/pir.2010.0011

Berdyaev, N. A. (1991). Samopoznanie [Self-actualization]. Leningrad: Lenisdat.

Berdyaev, N. A. (2000). Tvorchestvo i obyektivizacia [Creation and objectification] (A. G. Shimanskii \& Yu. O. Shimanskaya, Eds.). Minsk: Econompress.

Dyachenko, O. M. (1996). Problema razvitia sposobnostei do i posle L. S. Vygotskogo [The problem of the development of abilities before and after L. S. Vygotsky]. Voprosy Psychologii [Issues of psychology], 5, 98-109.

Florensky, P. A. (1994). Sochineniya [Works] (A. S. Trubachev, P. Florensky, \& M. S. Trubacheva, Eds.), 1. Moscow: Mysl. 
Frank, S. F. (1917). Dusha cheloveka. Opyt vvedenia v philosofskuyu psychologiyu [The soul of humans. Experience of the introduction to philosophical psychology]. Moscow: issue by G.A. Leman and S.M. Sacharov.

Gornfeld, A. (1912). O tolkovanii chudozhestvennogo proizvedenia [About the interpretation of a work of art]. Russkoe Bogatstvo [The Russian Wealth], 2, 145-172.

Lotman, Yu. M. (2000). Semiosfera [The semiosphere]. St. Petersburg: Iskusstvo.

Mamardashvili, M. K. (1996). Neobchodimost sebya. Lektsii. Statyi. Philosofskie zametki [The necessity of oneself. Lectures. Articles. Philosophical remarks] (Yu. P. Senokosov, Ed.). Moscow: Labirint.

Rubinstein, M. M. (1927). O smysle zhizni. Philosofia cheloveka [On the meaning of life. The philosophy of humans]. Part 2. Published by the author.

Shakespeare, W. (2007). Tragediya o Gamlete, printce Datskom. Per. s angl., vstupit. Statya i primechaniye M. L. Lozinskogo [The Tragedy of Hamlet, Prince of Denmark. Russian translation, introduction, and annotation by M. L. Lozinski]. St. Petersburg: Azbuka-klassika.

Shchedrovitsky, G. (1991). "Tragedia o Gamlete, prince datskom” L. S. Vygotskogo [“The Tragedy of Hamlet, Prince of Denmark" by L S. Vygotsky]. Voprosy metodologii [Issues of methodology], 4, 84-91.

Veraksa, N. E. (1990). Dialekticheskoe myshlenie i tvorchestvo [Dialectical thinking and creativity]. Voprosy psychologii [Issues of psychology], 4, 5-14.

Veraksa, N. E. (2000). Lichnost i kultura: Strukturno-dialekticheskii podhod [Personality and culture: A structural-dialectical approach]. Peremeny [Changes], 1, 81-107.

Veraksa, N. E. (2010). A structural approach to dialectic cognition. Psychology in Russia: State of the Art, 3, 227-239. doi: 10.11621/pir.2010.0011

Vygotsky, L. S. (1987). Psychologia iskusstva [The psychology of art] (M. G. Yaroshevsky, Ed.). Moscow: Pedagogika.

Yaroshevsky, M. G. (1996). Kogda Vygotsky i ego shkola poyavilis v psychologii? [When did L. S. Vygotsky and his school appear in psychology?] Voprosy psychologii [Issues of psychology], 5, 110-122. 